Acta vet. scand. $1959,1,19-26$.

From the Department of Sexual Physiology and Sexual Pathology Veterinary College of Norway, Oslo.

\title{
ISOLATION OF OESTRONE FROM THE URINE OF THE PREGNANT SOW
}

By

Weiert Velle.

In the sow, substances possessing oestrogenic activity are found in the urine at two periods during pregnancy. This peculiar fact was first demonstrated by Küst (1931) and Struck (1931), using biological methods. The authors found no oestrogenic activity in the urine during the first three weeks of pregnancy. Between the 23rd and 31st day, oestrogenic substances were excreted in amounts of $1000-2000$ M.U. per litre of urine. The activity then disappeared, and was not detected again until the 11 th or 12th week, from which time oestrogenic substances were excreted in increasing amounts until parturition, the maximum excretion being observed in the 15th week of pregnancy.

These earliest observations have been supported by later investigations based on bioassay (Heisig, 1932, Faermark \& Bigos, 1933, Faermark, 1935, Stiasny, 1937, Grunsell \& Roberson, 1953), and on the fluorescent test of Kober (1931) (Roth, Mayer \& Bogart, 1941, Grunsell \& Robertson, 1953).

However, as far as the present author is aware, no attempt has yet been made to identify the oestrogenic hormone or hormones. Thus Robinson (1957) states that oestrogens of unknown identity are excreted in the urine of the pregnant sow.

In the search of a method for early pregnancy diagnosis in the sow, it became necessary to elucidate the chemical nature of the oestrogenic substances. The observations reported in this paper indicate that oestrone is the only oestrogenic hormone excreted in significant quantities during pregnancy in this species. 


\section{EXPERIMENTAL}

Reagents.

The reagents used were of the same grade and from the same manufacturers as those used in a previous investigation concerning the urinary oestrogens of the boar (Velle, $1958 \mathrm{~b}$ ).

\section{Material.}

Samples of urine were collected from 2 sows during the last 2 weeks of pregnancy, from 12 sows 25 to 30 days pregnant, and from 5 non-pregnant sows. The qualitative analyses were undertaken immediately after the collection of the samples. Some of the urine specimens from sows in early pregnancy and from non-pregnant sows were $24-48$ hours old when assayed, due to transport from distant places. Observations indicate, however, that storing of the samples for some time, even at room temperature, does not cause appreciable changes in the oestrogen content of the urine.

\section{Methods.}

\section{A. Urine from sows in late pregnancy.}

The method described by Brown (1955) for the separate chemical determination of oestriol, oestrone and oestradiol-17 $\beta$ in human urine was used with minor modifications (Velle, 1958 a). As no significant quantities of oestriol and oestradiol could be detected by use of this method, these fractions were not further investigated.

Following acid hydrolysis, extraction, purification of the extracts, evaporation of the solvent, and partition of the residues between water and benzene-petroleum ether, the following tests were applied to the substance present in the organic phase:

1) Using the chromatographic method of Brown (1955), the elution pattern of the methylated oestrone fraction was compared with that of pure oestrone monomethyl ether added to the urinary extract from a non-pregnant sow.

2) Absorption spectra of methylated oestrone fractions isolated according to Brown (1955) were recorded from 400 to $600 \mathrm{~m} \mu$, using the Kober reagent modified by Bauld (1956).

3 ) Following reflux of the oestrone-oestradiol fraction in $50 \mathrm{cc}$ $1 \mathrm{n} \mathrm{NaOH}$ for 30 minutes in order to destroy certain contaminating substances (Bauld, 1956), the solutions were cooled, and 
$6 \mathrm{~g} \mathrm{NaHCO}_{3}$ was added to correct $\mathrm{pH}$ (Brown, 1956). The oestrogens were then extracted with two 25 cc portions of ethyl ether, the combined extracts washed with 5 cc water, and the ether evaporated. The residues were solved in 3 cc 2 per cent methanol in benzene and transferred to a chromatographic column with $3 \mathrm{~g}$ alumina (Merck, for chromatography), the column diameter being $10 \mathrm{~mm}$. The column was eluted with $3 \mathrm{cc}$ benzene, the effluent being discarded, and then with $20 \mathrm{cc} 2$ per cent methanol in benzene, the effluent being collected in one fraction. Model experiments using pure oestrone and oestradiol-17 $\beta$ had shown that amounts of $20 \mu \mathrm{g}$ of each of the compounds in mixture were totally eluted when this method was used. The procedure described is a modification of the method of Kakusjkina \& Orlova (1956), and is an efficient purification step, in addition to the fact that it partly serves to characterize the substances in question.

4) The effluent from the alumina column was evaporated in vacuo, and the residue chromatographed on a celite column according to Bauld (1956). This method permits the separate collection of oestrone and oestradiol in the free form. As no significant amounts of Kober chromogen could be detected in the oestradiol fraction, only the oestrone fraction was further investigated.

The residue after evaporation of the solvent from the oestrone fraction was subjected to the following tests:

5) Absorption spectra in fuming sulphuric acid were recorded from 240 to $500 \mathrm{~m} \mu$, according to the method described by Axelrod (1954).

6) The residue was coupled with diazotized p-nitrobenzeneazodimethoxyaniline and chromatographed on paper, according to the method of Heftman (1950).

B. Urine from non-pregnant sows and sows 25 to 30 days pregnant.

Urine samples from these animals were assayed using the method of Brown (1955) as modified by Velle (1958 a). Some samples of urine from non-pregnant sows were hydrolysed according to the method of Brown (1955), as this method has now been shown to give higher oestrogen values for urine from pigs (Velle, $1958 \mathrm{c}$ ).

Optical readings were made using a Beckman Model DU spectrophotometer supplied with photomultiplier. Quartz cuvettes 
were used for the recordings in the ultraviolet region. Cuvette dimensions $10 \mathrm{~mm}$.

\section{RESULTS}

Preliminary investigations using the Brown method revealed the presence of large quantities of a strongly reacting Kober chromogen in the oestrone fraction of urines from sows in late pregnancy.

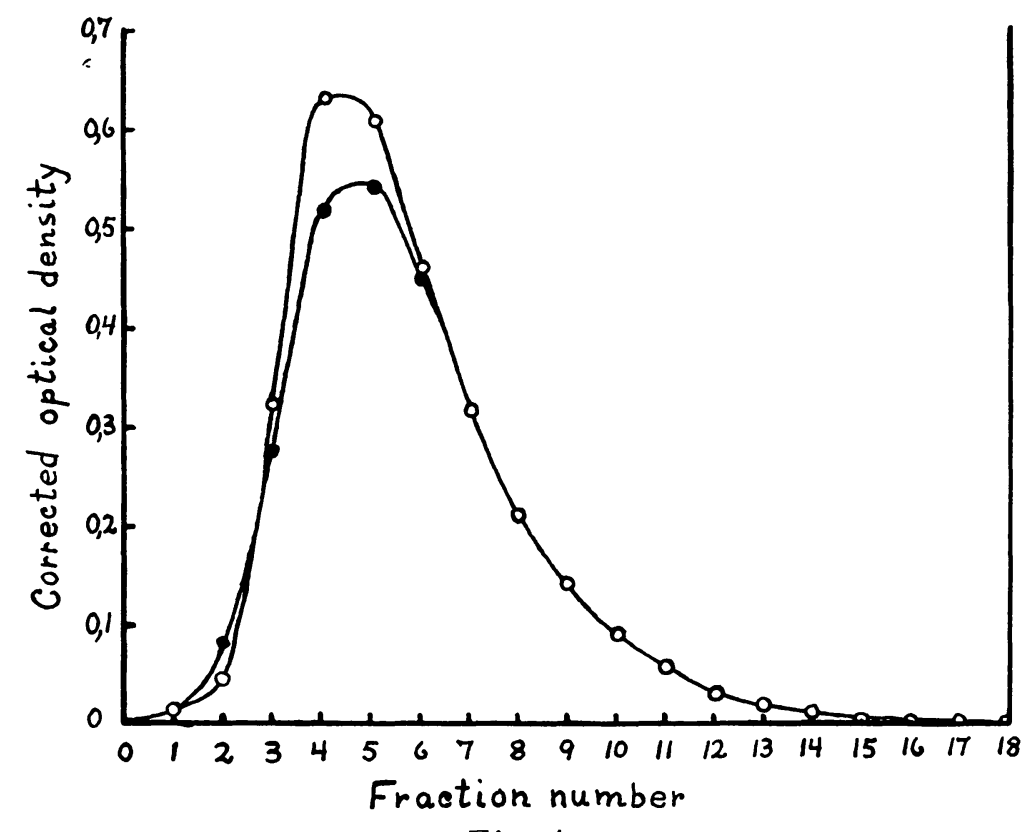

Fig. 1.

Chromatography of methylated oestrone fraction from pregnant sow's urine $\bullet-$, and of methylated oestrone fraction from non-pregnant sow's urine to which had been added $40 \mu \mathrm{g}$ pure oestrone monomethyl ether prior to chromatography o-o.

Solvents: 12 cc 25 per cent benzene in n-hexane (discarded), and 20 cc 40 per cent benzene in $n$-hexane, the effluent being collected in fractions of 1,15 cc.

The elution pattern of the isolated, methylated substance is shown in fig. 1. The substance is seen to behave chromatographically similarly to pure oestrone-monomethyl ether added to urinary extracts from non-pregnant sows.

In fig. 2 the absorption spectrum from 400 to $600 \mathrm{~m} \mu$ of the methylated substance in the modified Kober reagent is shown. 


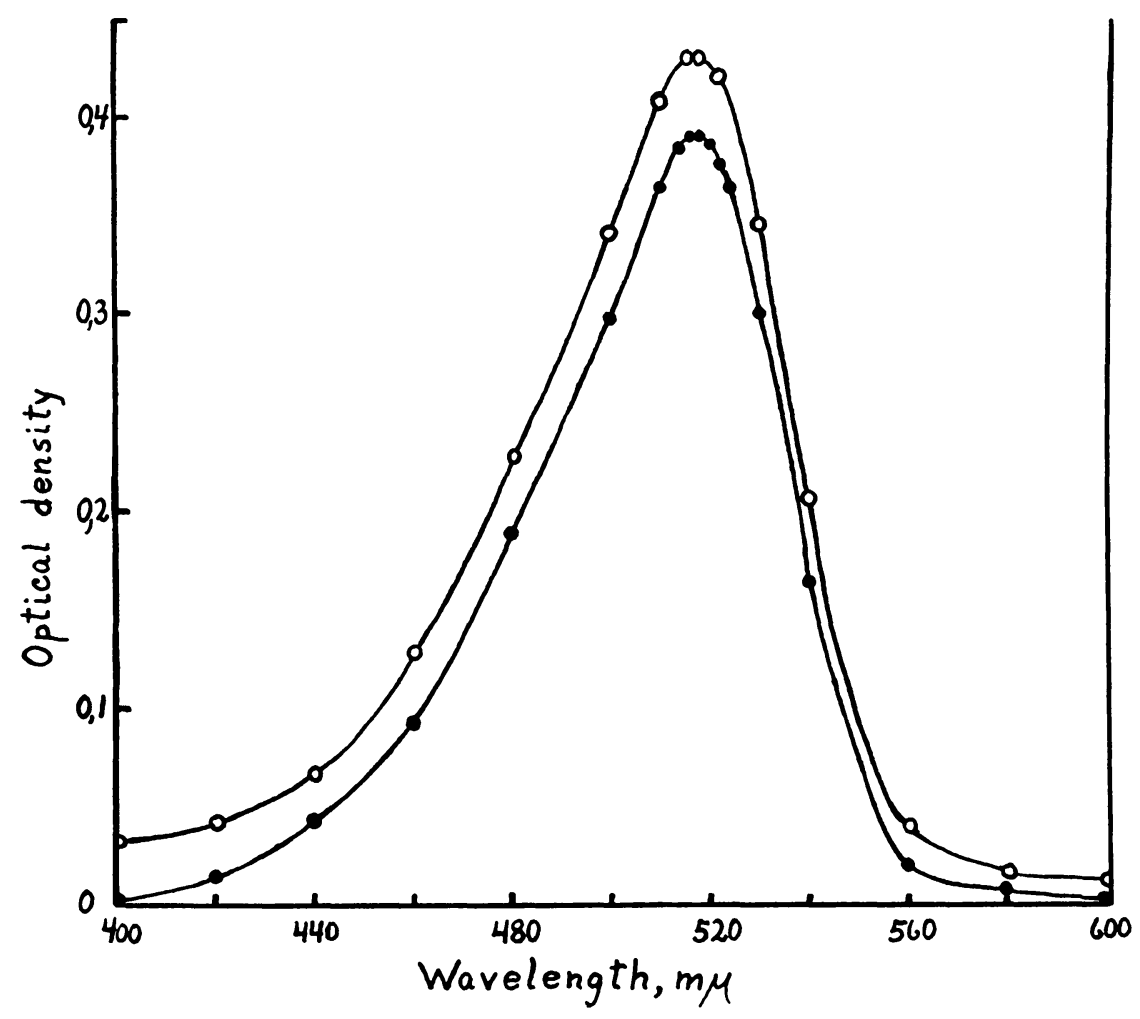

Fig. 2.

Absorption spectrum of methylated oestrone fraction from pregnant sow's urine - $\bullet$, and of $8 \mu \mathrm{g}$ pure oestrone monomethyl ether o- o, using the Kober reagent as modified by Bauld (1956).

The substance shows absorption maximum at the same wavelength as pure oestrone-monomethyl ether, at 516-518 $\mathrm{m} \mu$.

Following the extensive purification procedures described above, the substance showed the same characteristic absorption maximum at $300 \mathrm{~m} \mu$ as pure oestrone, using fuming sulphuric acid.

The derivative made by coupling the compound to diazotized p-nitrobenzeneazodimethoxyaniline had the same purple colour and upon chromatography gave the same $R_{f}$-value as the derivative of pure oestrone.

As regards the oestriol and oestradiol fractions, no significant quantities of Kober chromogens could be detected in late preg- 
nancy urine, using the Brown method. The same negative results applied to the urine from sows 25 to 30 days pregnant and from non-pregnant sows.

The urine of sows 25 to 30 days pregnant constantly showed increased amounts of the substance appearing in the oestrone fraction, the values being compared with those from non-pregnant sows. So far about 20 sows have been tested during this period, following insemination, and the results indicate a very high degree of specificity, when the method is applied as a pregnancy diagnosis test.

Also the urine from non-pregnant sows seems to contain measurable quantities of oestrone, at least at certain periods during the oestrous cycle. This point is being further investigated.

\section{DISCUSSION}

The reported results seem to permit the conclusion that the compound isolated from the phenolic fraction of urine from sows in late pregnancy is identical with oestrone. In addition to the similarity in chemical behaviour between the isolated Kober chromogen and oestrone, or their derivatives, in four different chromatographic systems, and the conformity between the recorded absorption spectra, support for the conclusion may also be sought in the fact that oestrone has been isolated from the ovary of the sow (Westerfeld et al., 1938). Further it has been observed that variations in the concentration of the isolated substance in urine are correlated with the sexual functions, and that the substance is found in greatest amounts in the periods of pregnancy when earlier investigators by use of biological methods have found the highest oestrogenic activity in the urine.

The isolation of the Kober chromogen in the oestrone fraction of pregnant sow's urine, and the failure to detect any appreciable quantities of oestriol and oestradiol, when applying the Brown method to the urine of pregnant and non-pregnant sows, indicate that oestrone is the main oestrogenic hormone excreted during pregnancy in this species. The presence of minute quantities of oestriol and oestradiol can, however, not be totally excluded on the basis of the analyses carried out.

From the results reported in this paper it follows that the application of a simplified Brown method for early pregnancy 
diagnosis in the sow is made possible. Results so far obtained indicate a very high degree of specificity when the method is applied to this purpose.

\section{Acknowledgements.}

This investigation has been partly supported by grants from the Agricultural Research Council of Norway.

The author is indebted to Ciba, Basel, for gifts of pure oestrogens.

\section{ADDED IN PROOF}

Through the courtesy of Dipl. Eng. S. Veige (AB Leo, Hälsingborg) the Kober chromogen isolated in the oestrone fraction of pregnant sow's urine has now been shown conclusively to be oestrone, by the use of infrared spectrographic analysis of the 3 -methyl derivative.

\section{REFERENCES}

Axelrod, L. R.: Recent Progr. Hormone Res. 1954, 9, 69.

Bauld, W. S.: Biochem. J. 1956, 63, 488.

Brown, J. B.: ibid. 1955, 60, 185.

Brown, J. B.: Personal communication, 1956.

Faermark, S. E.: Probl. Zooteh. exp. Endocrinol. 1935, 2, 48. Cited in: Cowie, A. T.: Pregnancy Diagnosis Tests. A Review. Commonwealth Agricultural Bureau Joint Publication No. 13. Great Britain, 1948, 283.

Faermark, S. E. \& Bigos, V.: Probl. Zivotn. 1933, 1, 73. Cited in: ibid. Grunsell, C. S. \& Robertson, A.: Vet. Rec. 1953, 65, 366.

Heftmann, E.: Science 1950, 111, 571.

Heisig, H.: Diss. Berlin 1932. Cited in Dtsch. tierärztl. Wschr. 1934, $42,408$.

Kakusjkina, E. A. \& Orlova, V. G.: Biokhimija 1956, 21, 26.

Kober, S.: Biochem. Z. 1931, 239, 209.

Küst, D.: Dtsch. tierärztl. Wschr. 1931, 39, 738.

Robinson, T. J.: Pregnancy, pp 793-904 in: Hammond, J.: Progress in the Physiology of Farm Animals, Vol. 3. Butterworth Scientific Publications. London 1957.

Roth, S. Y., Mayer, D. T. \& Bogart, R.: Amer. J. vet. Res. 1941, $2,436$.

Stiasny, H.: Z. Geburtsh. Gynäk. 1937, 116, 108.

Struck, M.: Diss. Giessen 1931.

Velle, W.: Acta endocr. (Kbh.) 1958 a, 27, 64.

Velle, W.: Acta endocr. (Kbh.) 1958 b, 28, 255.

Velle, W.: Unders $\varnothing$ kelser over naturlig forekommende $\phi$ strogener hos drøvtyggere og gris. Oslo, $1958 \mathrm{c}, 162$.

Westerfeld, W. W., Thayer, S. A., MacCorquodale, D. W. \& Doisy, E. A.: J. biol. Chem. 1938, 126, 181. 


\section{SUMMARY}

By means of chromatographic and spectrophotometric methods the presence of oestrone in the urine from sows in late pregnancy has been demonstrated.

Using the method of Brown (1955) for chemical determination of urinary oestrogens, small amounts of oestrone were also detected in the urine from non-pregnant sows. Considerable increases in the concentration of oestrone were regularly observed in urines from sows 25 to 30 days pregnant. This observation makes possible the application of a simplified Brown method for early pregnancy diagnosis in this species.

No significant amounts of oestriol and oestradiol could be detected in the urine from non-pregnant and pregnant sows, when the Brown method was applied.

\section{ZUSAMMENFASSUNG}

Isolierung von östron aus dem Harn trächtiger Säue.

Mit Hilfe chromatographischer und spektrophotometrischer Methoden gelang es, aus dem Harn trächtiger Säue im letzten Teil der Trächtigkeitsperiode östron zu isolieren.

Kleine Mengen von östron liessen sich auch im Harn nichtträchtiger Säue beim Gebrauch der Methode von Brown zur chemischen Bestimmung von östrogenen im Harn nachweisen (Brown, 1955). Im Harn von Säuen, die zwischen dem 25. und 30. Tage trächtig waren, wurde eine Steigerung im Gehalt von östron im Harn konstant wahrgenommen. Diese Beobachtung ermöglicht die Anwendung einer vereinfachten Brown-Methode in der Diagnose zeitiger Trächtigkeit beim Schwein.

östriol und östradiol konnten mittels der Methode nach Brown nicht nachgewiesen werden. Dies gält sowohl für trächtige als auch nichtträchtige Säue.

\section{SAMMENDRAG}

Isolering av фstron i urin fra drektig purke.

Ved hjelp av kromatografiske og spektrofotometriske metoder har det lykkes å isolere $\varnothing$ stron $\mathrm{i}$ urin fra drektige purker i siste del av drektighetsperioden.

Små mengder av фstron kunne også påvises i urin fra ikke-drektige purker ved benyttelse av Brown's metode til kjemisk bestemmelse af $\varnothing$ strogener i urin (Brown, 1955). I urin fra purker drektige mellom 25. og 30. dag ble det konstant iakttatt $\varnothing \mathrm{kning}$ i urinens innhold av $\emptyset$ stron. Denne observasjon muliggjør anvendelsen av en forenklet Brown-metode i diagnosen av tidlig drektighet hos gris.

Østriol og Østradiol kunne ikke påvises ved hjelp av Brown's metode. Dette gjaldt for både drektige og ikke drektige purker. 